\title{
The Distribution and Morphology Alterations of Microfilaments and Microtubules in Mesophyll Cells and Root-Tip Cells of Wheat Seedlings under Enhanced Ultraviolet-B Radiation
}

\author{
Limei Gao', Yongfeng Li ${ }^{1,2}$, Aihua Guo ${ }^{3}$, Jingru Zhai', Rong Han ${ }^{*}$ \\ ${ }^{1}$ Higher Education Key Laboratory of Plant Molecular and Environmental Stress Response, Shanxi Normal \\ University, Linfen, China \\ ${ }^{2}$ Analysis and Testing Center, Shanxi Normal University, Linfen, China \\ ${ }^{3}$ Departrment of Life Science, Lvliang University, Lvliang, China \\ Email: ${ }^{\text {hhwrsl@163.com }}$
}

Received 26 September 2014; revised 25 October 2014; accepted 10 November 2014

Copyright (C) 2014 by authors and Scientific Research Publishing Inc.

This work is licensed under the Creative Commons Attribution International License (CC BY). http://creativecommons.org/licenses/by/4.0/

c) (i) Open Access

\section{Abstract}

The distribution and morphology alterations of microfilaments and microtubules in the mesophyll cells and root-tip cells of wheat seedlings, which had been radiated by enhanced ultraviolet-B $\left(10.08 \mathrm{KJ} \cdot \mathrm{m}^{-2} \cdot \mathrm{d}^{-1}\right)$, were examined through the confocal laser scanning microscope (Model FV1000, Olympus, Japan). Microtubule was labeled with an indirect immunofluorescence staining method, and microfilament was labeled with fluorescein isothiocyanate-phalloidin (FITC-Ph) as probes. The results indicated that microtubules in mesophyll cells, compared with the controls, would be depolymerized significantly, and dispersed randomly showing some spots or short rods in the cytoplasm, under the enhanced UV-B radiation condition. The microtubule bundles tended to be diffused, and the fluorescence intensity of that significantly decreased. The distribution pattern of microfilaments, which usually arranged parallelly in control cells, was broken up by enhanced UV-B radiation. We further investigated the distribution and morphology of microtubules in root-tip cells during every stage of cell division, and found that these aberrant phenomena of microtubules were often associated with abnormal cell division. Our findings suggested that the distribution, morphology and structure of cytoskeleton in mesophyll cells and root-tip cells of wheat seedlings would be affected by enhanced UV-B radiation, which might be related to abnormal cell division caused by enhanced UV-B radiation as an extracellular signal.

${ }^{*}$ Corresponding author.

How to cite this paper: Gao, L.M., Li, Y.F., Guo, A.H., Zhai, J.R. and Han, R. (2014) The Distribution and Morphology Alterations of Microfilaments and Microtubules in Mesophyll Cells and Root-Tip Cells of Wheat Seedlings under Enhanced Ultraviolet-B Radiation. American Journal of Plant Sciences, 5, 3423-3431. http://dx.doi.org/10.4236/ajps.2014.522358 


\title{
Keywords
}

\author{
Wheat, Microfilament, Microtubule, Enhanced UV-B Radiation, Confocal Laser Scanning \\ Microscope
}

\section{Introduction}

With the acceleration development of global industrialization, the environment problem becomes more and more serious, which will increase the Ultraviolet-B (UV-B, the wavelength range of $290 \mathrm{~nm}-320 \mathrm{~nm}$ ) radiation that reaches the surface of the earth [1] [2]. The enhanced UV-B radiation can directly affect the growth and development of many organisms and may further threaten human beings [3] [4]. In the early 1990s', the influence of enhanced UV-B radiation on the growth of living organisms had been extensively concentrated. Recently, lots of researches have indicated that enhanced UV-B radiation can arouse significant effects on living organisms in morphological structures, physiological processes, biochemical metabolism, photosynthesis, gene expression and so on [5]-[7]. Therefore, it is necessary to study further the mechanism of enhanced UV-B radiation damage on organisms, especially crops, in order to obtain some effective protection methods [8].

The microfilament and microtubule are two crucial cytoskeleton components in eukaryotic cells, which play an important role in cell form maintenance, cells or organelles migration, many inorganic or organic substances transport, cell signal transduction, and cell reproduction regulation [9]. However, there are relative few reports about the effects of enhanced UV-B radiation on microfilament and microtubule systems in cells [10], including the relationship between microfilament or microtubule systems and abnormal cell division. Whether the growth change of living organisms is related to the change of cytoskeleton under enhanced UV-B radiation, and how the enhanced UV-B radiation affects microfilament or microtubule. These problems need to be solved as soon as possible [11].

Confocal laser scanning microscope is a kind of essential method for researching cellular or subcellular structures and components, and the application of which establishes a perfect pathway for studying further submicroscopic structures in cells and organelles [12].

During our researches, the influence of enhanced UV-B radiation on microfilament and microtubule systems in mesophyll cells and root-tip cells had been measured through selecting wheat seedlings as experimental materials. The purpose of this study was aimed at exploring the distribution and morphology alterations of cytoskeleton system in cells of wheat seedlings under enhanced UV-B radiation, in order to explain the effects and injury mechanism for enhanced UV-B radiation on growth and development of wheat seedlings [13]. Research achievements of this work may provide theoretical foundation and experimental systems for studying effects of unfavorable environment factors on cytoskeleton system in plant cells.

\section{Materials and Methods}

\subsection{Plant Materials and Culture}

Seeds of winter wheat (Triticum aestium, cv. 93-4736) were used as materials for this research and obtained from Wheat Research Institute, Shanxi Agricultural Sciences Academy, China. Uniform size and plump seeds were selected and washed repeatedly more than 3 times with sterilized water after being surface sterilized in $0.1 \%$ $\mathrm{HgCl}_{2}$ solution for 2 - $3 \mathrm{~min}$, then incubated in Petri dishes (diameter $18 \mathrm{~cm}$ ) with wet filter paper [14]. There were 3 replications, each containing 50 granules. These seeds in Petri dishes were cultured for $3 \mathrm{~d}$, at $24^{\circ} \mathrm{C} \pm 2^{\circ} \mathrm{C}$, relative humidity $70 \%$, in a plant growth chamber under darkness until germination [14].

\subsection{Experimental Methods}

Enhanced UV-B radiation was provided by a filter lamp (Qin brand, 30W, Baoji Lamp Factory, Baoji city, China) according to the procedure described by Lydon et al. [15]. The UV-B radiation intensity was 10.08 $\mathrm{KJ} \cdot \mathrm{m}^{-2} \cdot \mathrm{d}^{-1}$, which was equivalent to the supplemental level with $20 \%$ stratospheric ozone reduction or $40 \%$ UV-B radiation enhancement during a clear day [16]. In addition to enhanced UV-B radiation, the visible light radiation was also supplied for $8 \mathrm{~h}$ per day at the same time [17]. Wheat seedlings were treated constantly for 7 
days, and then were harvested for further being measured.

In our studies, the wheat seedlings were divided into two groups: the control group (C, only visible light radiation, without enhanced UV-B radiation) and enhanced UV-B radiation treatment group (B).

\subsection{Protoplasts Preparation and Activities Detection}

Fresh leaves (about $5.0 \mathrm{~g}$ ) of wheat seedlings were immersed in hydrolytic solution and treated about $3 \mathrm{~h}$ at $26^{\circ} \mathrm{C}$ $\pm 1^{\circ} \mathrm{C}$ under darkness. The hydrolytic solution containing leaf tissues was vibrated one time at interval half an hour. The ratio of leaf tissues and hydrolytic solution was 1:5 (w/v), and the hydrolytic solution was configurated by using standard solution with $1.5 \%$ cellulase R-10 (Japan) and $0.1 \%$ pectinase (Fluka). When enzyme treatment finished, mesophyll tissue being incompletely digestive were filtered by 20 mesh nylon net. Then desirable protoplasts were collected through centrifuging at $500 \mathrm{r} / \mathrm{min}$ and washed 2 times with PBS buffer. Subsequently, these protoplasts were mixed with $25 \mathrm{mg} / \mathrm{ml}$ fluorescein diacetate (FDA, Sigma F7378) in proportion to $1: 1(\mathrm{v} / \mathrm{v})$ and placed at room temperature about $10 \mathrm{~min}$ for detecting protoplasts activities.

\subsection{Microfilament Label in Protoplast of Mesophyll Cells}

Microfilaments were labeled with $200 \mathrm{nmol} / \mathrm{L}$ FITC-Ph and incubated about $2 \mathrm{~h}$ at $26^{\circ} \mathrm{C}$ under darkness. At the same time, the comparison group was established and treated under the above circumstance, but in which protoplasts were not labeled with FITC-Ph or labeled with $10 \%$ hydroxypropyl-beta-cyclodextrin (Hp- $\beta$-CD, Sigma) for $2 \mathrm{~h}$.

\subsection{Microtubule Label in Protoplast of Mesophyll Cells and Root-Tip Cells}

The microtubules were marked by indirect immunofluorescence antibody localization technology. At first, mesophyll protoplasts in wheat seedlings were fixed with $3.7 \%$ polyoxymethylene for $30 \mathrm{~min}$, extracted with $0.5 \%$ triton X-100 for 20 min and washed with phosphate buffer saline (PBS) for 3 times, 5 min per time. Then protoplasts were sealed with $3 \%$ bovine serum albumin (BSA) for 15 min. The suspension of protoplasts were mixed with mouse monoclonal antibody (Sigma, USA) in accordance with the proportion of 1:160 (v/v) and incubated for $1.5 \mathrm{~h}$ at $37^{\circ} \mathrm{C}$, then washed with PBS buffer for 5 times. The suspension of protoplasts were immediately marked with Texas-red IgG (Invitrogen) in accordance with the proportion of 1:200 (v/v) and incubated for $1 \mathrm{~h}$ at $37^{\circ} \mathrm{C}$ again, washed with PBS buffer for 5 times, 5 min per time. At last, bio-loaded section were sealed immediately with 50\% glycerine. In the meanwhile, the control group (C) was set, in which protoplasts were incubated mixed with $3 \%$ BSA instead of mouse monoclonal antibody.

Microtubules in root-tip cells were labeled according to the above procedure. The difference was that root-tips should be enzymolyzed ( $1 \%$ cellulose R-10 and $1 \%$ pectinase) prior to being extracted with $0.2 \%$ triton X-100 and washing buffer was PEM instead of PBS.

\subsection{Microfilament and Microtubule Microscopic Observation}

The distribution and morphology of microfilaments and microtubules were observed through confocal laser scanning microscope (FV1000, Olympus, Japan), with an excitation wavelength at $488 \mathrm{~nm}$ or $543 \mathrm{~nm}$.

\section{Results}

\subsection{Mesophyll Protoplasts of Wheat Seedlings Preparation and Activities Measurement}

The desirable mesophyll protoplasts of wheat seedlings were obtained with enzymatic method. There were lots of spherical protoplasts packaged by a thin layer of plasma membrane under the optical microscope, in which many green chloroplasts distributed. These protoplasts were stained with FDA indicator and detected with the confocal laser scanning microscope under $488 \mathrm{~nm}$ excitation light. We would find that most of protoplasts still showed green fluorescence brightly, which demonstrated that these protoplasts were high dynamic (Figure 1(a)).

\subsection{Influence of Enhanced UV-B Radiation on Microfilaments in Mesophyll Cells of Wheat Seedlings}

In mesophyll protoplasts of $\mathrm{C}$ group, we found that microfilaments system mainly arrayed in parallel rows with 
confocal laser scanning microscope (Figure 1(b)), the morphology and distribution of which was consistent with the results of Chen et al. [18]. However, when being radiated by enhanced UV-B, only few of microfilaments aggregated into microfilament bundles, others depolymerized into dot-like or fragmentary (Figure 1(c)). But being treated with CD depolymerization agent, microfilaments system would be destroyed completely (Figure $1(\mathrm{~d})$ ).

\subsection{Influence of Enhanced UV-B Radiation on Microtubules in Mesophyll Cells of Wheat Seedlings}

In C group, cortical microtubules in mesophyll cells distributed over the whole cytoplasm and took on threedimensional network structure (Figure 1(e)). While in B group, microtubules system arrayed disorderly and presented punctiform or segment-like (Figure 1(f)). As a consequence, cortical microtubules depolymerized significantly under enhanced UV-B radiation.
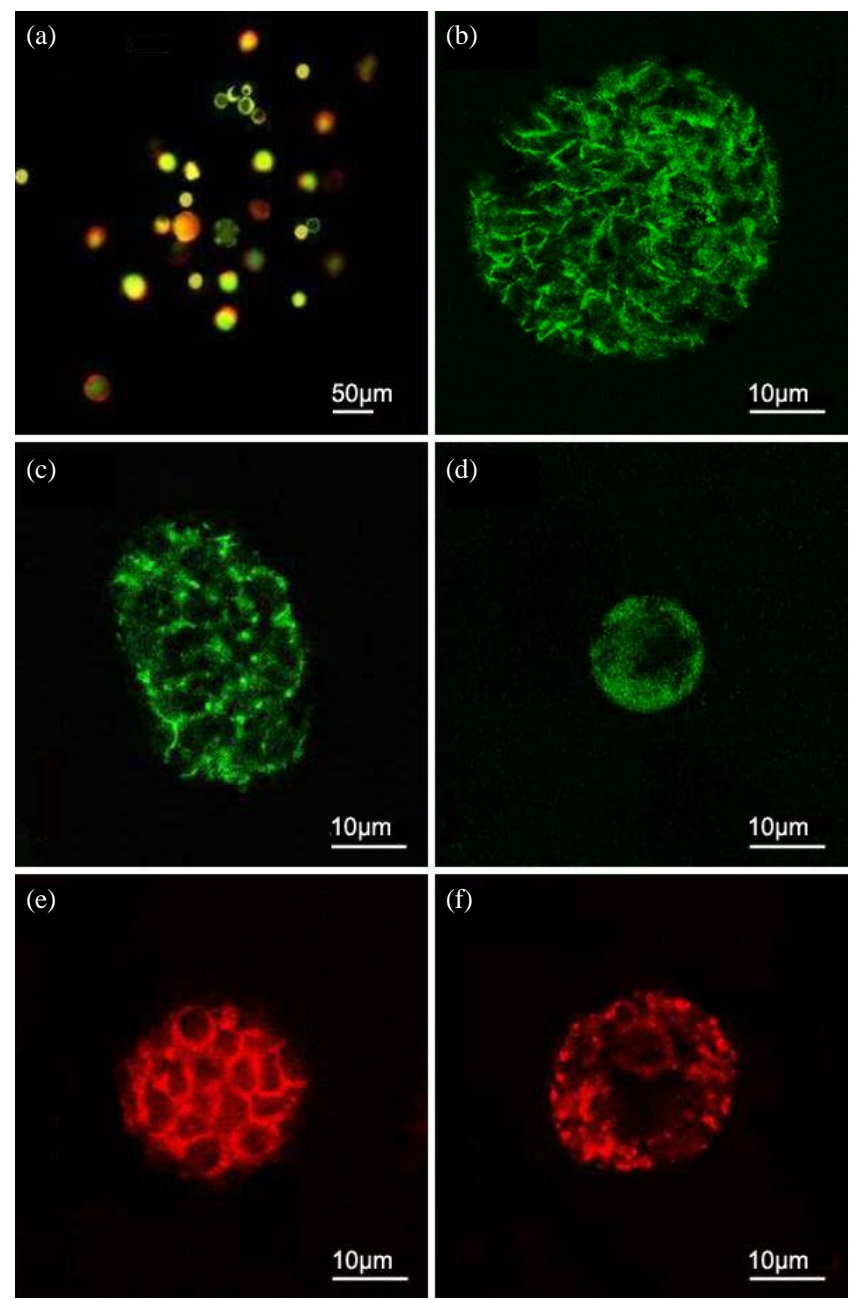

Figure 1. Influence of enhanced UV-B radiation on microfilaments and microtubules in mesophyll cells. (a) Purification and activity assay of wheat mesophyll protoplasts; (b) Microfilaments in wheat mesophyll protoplasts of control group; (c) Microfilaments in wheat mesophyll protoplasts after enhanced UV-B radiation; (d) Microfilaments in wheat mesophyll protoplasts being treated by Hp- $\beta$-CD; (e) Microtubules in wheat mesophyll protoplasts of control group; (f) Microtubules in wheat mesophyll protoplasts after enhanced UV-B radiation. 


\subsection{The Distribution and Morphology of Microtubules in Root-Tip Cells during Cell Division}

The cytoskeleton of microtubules were labeled with indirect immunofluorescence localization method, and observed through confocal laser scanning microscope. There were different microtubule arrangement types in cell division cycle of $\mathrm{C}$ group cells, including cortical microtubules in cell inter-phase (Figure 2(a)), pre-prophase band (PPB, Figure 2(b)) and perinuclear microtubules (Figure 2(c)) in cell prophase, complete spindle body in cell metaphase (Figure 2(d)), spindles and polar microtubules (Figure 2(e)) in anaphase, phragmoplast microtubules (Figure 2(f), Figure 2(g)) in the last phase of cells. And when cell division finished, the phragmoplast
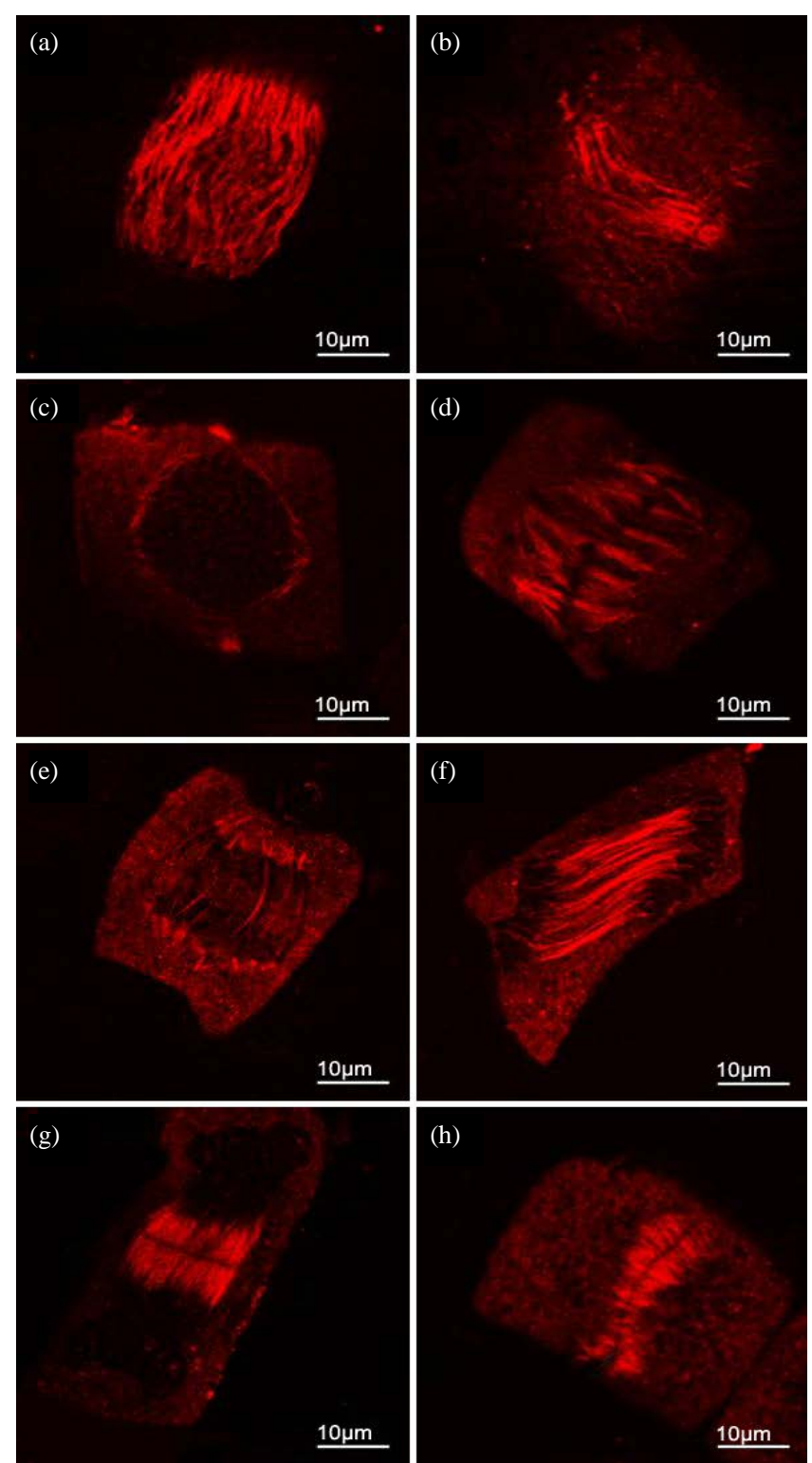

Figure 2. The microtubules distribution and morphology during cell division every stage in root-tip cells of wheat seedlings in C. (a) Cortical microtubules in cell interphase; (b) Preprophase band; (c) Perinuclear microtubules in cell prophase; (d) Complete spindle body in cell metaphase; (e) Spindles and polar microtubules in anaphase; (f), (g) Phragmoplast microtubules; (h) Deposition of cell plate. 
microtubules disappeared accompanied with deposition of cell plate (Figure 2(h)), the cortical microtubules formed again in cytoplasm.

However, we found that quite a few of microtubules abnormal arrangement phenomenon happened in root-tip cytoplasm, and most of microtubules system would be damaged partially under enhanced UV-B radiation. Compared with the controls, microtubules system displayed periodic arrangement in B group root-tip cells. Microtubules arrayed with network-like (Figure 3(a)) or depolymerized into scattered punctuate (Figure 3(b)) in inter-phase. When getting into prophase, two pre-prophase bands would form in cytoplasm of B group (Figure 3(c)), which also was found in studies of Huang et al. [19]. And in cell metaphase, few of microtubules gathered spindle fiber, the intact spindle was invisible (Figure 3(d)). Microtubules bundles were unconspicuous in the last phase of cells (Figure 3(e)), the phragmoplast microtubules would not come into being (Figure 3(f)). Therefore, we speculated that the aberrant phenomenon of microtubules during cell division might be one of the main reasons of cell variation.

\section{Discussion}

Microfilaments and microtubules system are major components of cytoskeleton in eukaryotic cells, which are essential for lots of physiological processes and biochemical metabolism in living organisms [20]. Previous
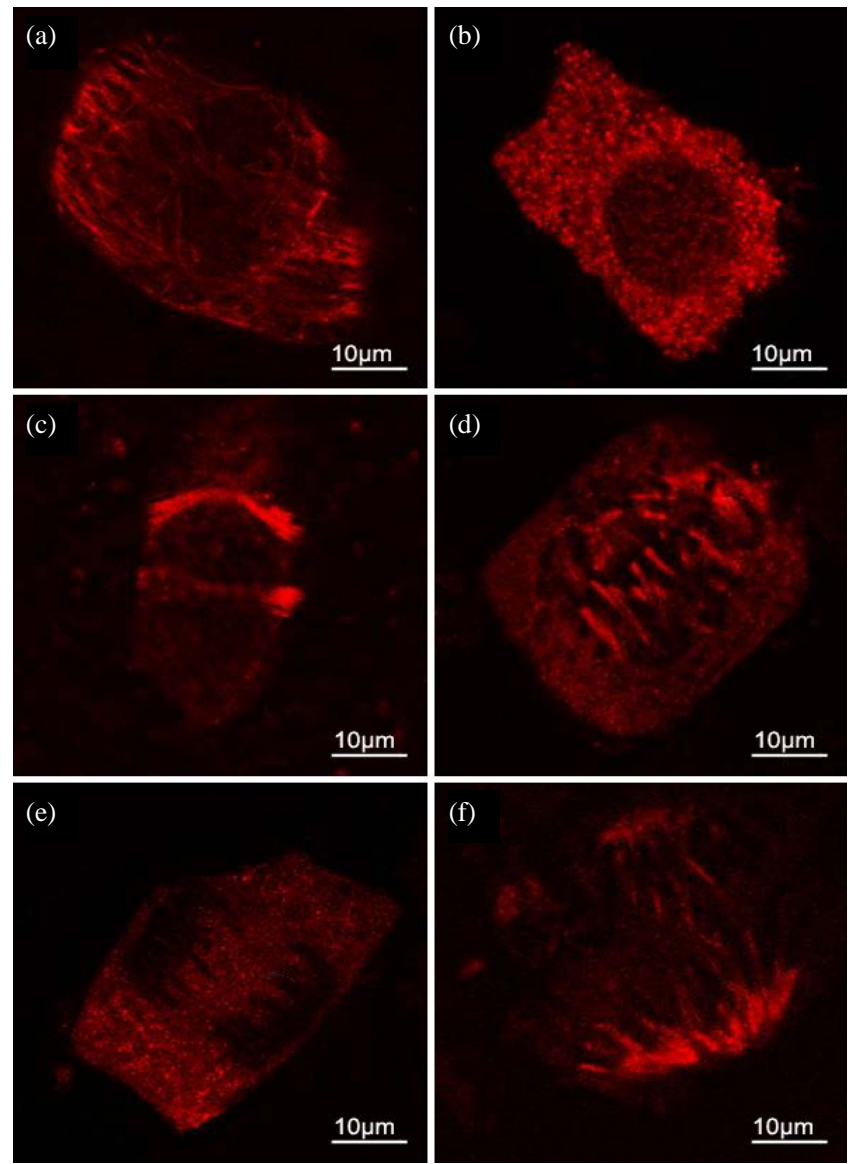

Figure 3. The distribution and morphology of microtubules during cell division every stage of in root-tip cells in B. (a) Microtubules arrayed with network-like in interphase; (b) Other microtubules depolymerized into scattered punctuate; (c) Two preprophase bands in cytoplasm in prophase; (d) Few of microtubules only gathered spindle fiber in cell metaphase; (e) Unconspicuous microtubules bundles; (f) Phragmoplast microtubules were invisible. 
studies on cytoskeleton mainly focused on animal cells, and there were rarely researches or reports about cytoskeleton morphological alterations and molecular mechanism using plant cells as materials. Recently, with the continuous improvement of research technology in life sciences, the understandings about microfilaments and microtubules in plant cytoplasm are becoming urgently needed.

Plant tissues or cells are normally able to response on numerous environmental stimulating factors, such as UV-B radiation [11], calcium influx [21], following simultaneously cytoplasmic reorganization rapidly, the occurrence of which usually mediated or regulated by the complex microfilaments and microtubules system in plant cells [22]. Chen et al. discovered, selecting wheat-leaf rust interaction system as experimental materials, that the microfilaments could keep complete network-like structure in protoplasts of disease-resistant wheat, however, most of microfilaments in ones of susceptible wheat were in a state of depolymerization [18]. Studies of Wang et al. had declared that Bipolaris maydis $\mathrm{C}$ would bring about protoplast contraction, protoplast leakage and microfilament distribution abnormalities in maize root-cap cells [23]. Lei et al. also found that microfilament systems would gather into bundles or take on fragmentary when rice root-cap cells had been treated with bacterial blight toxin [24]. Ren et al. researched the effects of nitrogen ion implantation on pollen germination and microfilaments, and revealed that microfilaments would be ring bundle state or concentrated parallel structure induced by low-energy nitrogen ions, which mainly distributed in pollen germination groove [25]. Then, whether does the enhanced UV-B radiation affect microfilaments and microtubules of wheat seedlings as one of external stimulation signals. Few of works on this problem has been done until today.

A large number of studies have shown that enhanced UV-B radiation could lead to some abnormal phenomenon in living organisms, such as bio-membrane damage, membrane surface charge reduction, membrane permeability enhancement, cell electrophoresis rate decline, chromosome morphology alteration and aberrant cell division [26]-[28]. R. Han et al. (2002) found that the enhanced UV-B radiation would cause "root-bending" phenomenon when wheat seeds germination and "partition-bundle" division in root-tip cells of wheat seedlings [28]. Cell wall-plasma membrane-cytoskeleton have formed continuum in plant cells [29]. In our study, the morphology and distribution pattern of microfilament and microtubule in wheat seedlings, especially in root-tip cell, were significantly changed under enhanced UV-B stress. Furthermore, the distribution alteration of microtubule at cell division every stage in root-tip cell suggested that the spindle assembling was affected and chromosome separation and movement were hindered, due to the microtubule was the predominant components of the spindle. As a result, one of the main reasons of above abiotic injury including "partition-bundle" division, might be that UV-B radiation participated in signal transduction as a kind of extracellular signal, and caused the corresponding biological reaction or physiological processes, finally led to cytoskeleton morphology and distribution alterations.

\section{Conclusion}

In the present study, we found that the morphology and distribution of microfilaments and microtubules in mesophyll cells all had greatly changed, such as taking on dot-like or diffused fragments randomly under enhanced UV-B radiation. At the same time, the distribution and morphology of microtubules in root-tip cells also had been remarkably influenced by enhanced UV-B radiation during cell cycle, which might be one of the predominent reasons on the aberrant cell division (such as partition bundle division [27] in root-tip cell) caused by enhanced UV-B radiation.

\section{Acknowledgements}

This research work was supported by the National Nature Science Foundation of People's Republic of China (Grant No. 31301245), and the Nature Science Foundation of Shanxi Normal University (Grant No. ZR1414).

\section{References}

[1] Rousseaux, C.M., Flint, S.D., Searles, P.S. and Caldwell, M.M. (2004) Plant Responses to Current Solar Ultraviolet-B Radiation and Supplemented Solar Ultraviolet-B Radiation Simulating Ozone Depletion: An Experimental Comparison. Photochemistry and Photobiology, 80, 224-230. http://dx.doi.org/10.1562/2004-03-30-RA-129.1

[2] Allen, D.J., Nogués, S. and Baker, N.R. (1998) Ozone Depletion and Increased UV-B Radiation Is There a Real Threat to Photosynthesis? Journal of Experimental Botany, 328, 1775-1788.

[3] Tanaka, A., Sakamoto, A., Ishigaki, Y., Nikaido, O., Sun, G. and Hase, Y. (2002) An Ultraviolet-B-Resistant Mutant 
with Enhanced DNA Repair in Arabidopsis. Plant Physiology, 129, 64-71. http://dx.doi.org/10.1104/pp.010894

[4] Fabón, G., Monforte, L., Tomás-Las-Heras, R., Núñez-Olivera, E. and Martínez-Abaigar, J. (2012) Dynamic Response of UV-Absorbing Compounds, Quantum Yield and the Xanthophyll Cycle to Diel Changes in UV-B and Photosynthetic Radiation in an Aquatic Liverwort. Journal of Plant Physiology, 169, $20-26$. http://dx.doi.org/10.1016/j.jplph.2011.08.010

[5] Yu, J., Tang, X.X. and Zhang, P.Y. (2005) Physiological and Ultralstructural Changes of Chlorella sp. Induced by UV-B Radiation. Progress of Nature Science, 15, 678-683. http://dx.doi.org/10.1080/10020070512331342750

[6] Mulpuri, V.R., Gopinadhan, P. and Douglas, P.O. (1996) Ultraviolet-B and Ozone-lnduced Biochemical Changes in Antioxidant Enzymes of Arabidopsis thaliana. Plant Physiology, 110, 125-136. http://dx.doi.org/10.1104/pp.110.1.125

[7] Hopkins, L., Bond, M.A. and Tobin, A.K. (2002) Ultraviolet-B Radiation Reduces the Rates of Cell Division and Elongation in the Primary Leaf of Wheat (Triticum aestivum L. cv Maris Huntsman). Plant Cell Environment, 25, 617-624. http://dx.doi.org/10.1046/j.1365-3040.2002.00834.x

[8] Yang, L.Y., Han, R. and Sun, Y. (2013) Effects of Exogenous Nitric Oxide on Wheat Exposed to Enhanced Ultraviolet-B Radiation. American Journal of Plant Sciences, 4, 1285-1290. http://dx.doi.org/10.4236/ajps.2013.46159

[9] Xu, S.X. and Zhu, W. (1996) Plant Cell Cytoskeleton. Science Press, Beijing, 60-83, 94-104. (In Chinese)

[10] Leena, L., Päivi, M.J. and Marikki, L. (2008) Cytoskeleton-Interacting LIM-Domain Protein CRP1 Suppresses Cell Proliferation and Protects from Stress-Induced Cell Death. Experimental Cell Research, 314, 738-747. http://dx.doi.org/10.1016/j.yexcr.2007.11.024

[11] Weber, C., Marchat, A.L., Guillen, N. and López-Camarillo, C. (2009) Effects of DNA Damage Induced by UV Irradiation on Gene Expression in the Protozoan Parasite Entamoeba histolytica. Molecular and Biochemical Parasitology, 164, 165-169. http://dx.doi.org/10.1016/j.molbiopara.2008.12.005

[12] Katulaemail, K.S., Heinloth, A.N. and Paules, R.S. (2007) Folate Deficiency in Normal Human Fibroblasts Leads to Altered Expression of Genes Primarily Linked to Cell Signaling, the Cytoskeleton and Extracellular Matrix. Journal of Nutritional Biochemistry, 18, 541-552. http://dx.doi.org/10.1016/j.jnutbio.2006.11.002

[13] Perveen, R., Ali, Q., Ashraf, M., Al-Qurainy, F., Jamil, Y. and Raza, A.M. (2010) Effects of Different Doses of Low Power Continuous Wave He-Ne Laser Radiation on Some Seed Thermodynamic and Germination Parameters, and Potential Enzymes Involved in Seed Germination of Sunflower (Helianthus annuus L.). Photochemistry and Photobiology, 86, 1050-1055. http://dx.doi.org/10.1111/j.1751-1097.2010.00782.x

[14] Zhang, J. and Han, R. (2009) Effects of He-Ne Laser and UV-B Radiation on $\mathrm{Na}^{+} / \mathrm{K}^{+}$-ATPase Activity in Organelles of Wheat Seedlings. Chinese Bulletin of Botany, 44, 451-456. (In Chinese)

[15] Lydon, J., Teramura, A.H. and Summers, E.G. (1986) Effects of Ultraviolet-B Radiation on Growth and Productivity of Field-Grown Soybean. In: Stratospheric Ozone Reduction, Solar Ultraviolet Radiation and Plant Life, SpringerVerlag, Berlin, 313-325.

[16] Wang, X.H., Hao, J.H. and Han, R. (2008) The Alleviating Effects of He-Ne Laser on Membrane Lipid Peroxidation in Wheat Seedling Exposed to Enhanced Ultraviolet-B Irradiation. Acta Laser Biology Sinica, 17, 317-322. (In Chinese)

[17] Feng, H.Y., An, L.Z., Tan, L.L., Hou, Z.D. and Wang, X.L. (2000) Effects of Enhanced Ultraviolet-B Radiation on Pollen Germination and Tube Growth of Taxa in Vitro. Environmental and Experimental Botany, 43, 45-53. http://dx.doi.org/10.1016/S0098-8472(99)00042-8

[18] Chen, X.B., Wang, D.M., Liu, J. and Wang, Z.X. (2002) Effect of Wheat Leaf Eluant on Microfilaments Cytoskeleton of Mesophyll Cells by Cultured Leaf Rust. Journal of Plant Physiology and Molecular Biology, 28, 344-350. (In Chinese)

[19] Huang, S.J. (2005) Analysis of Plant Microtubule Array Organization, Transition and Plant Microtubule Dynamics in Vitro. Ph.D. Thesis, Chinese Agriculture University, Beijing. (In Chinese)

[20] Yu, R., Yuan, M. and Wang, X.C. (1998) Dynamics and Regulation of Microtubule System. Chinese Bulletin of Botany, 15, 19-29.

[21] Luo, M.Z., Yang, Z.Q., Li, J.B., Xu, H.Y., Li, S.S., Zhang, W., Qian, A.R. and Shang, P. (2013) Calcium Influx through Stretch-Activated Channels Mediates Microfilament Reorganization in Osteoblasts under Simulated Weightlessness. Advances in Space Research, 51, 2058-2068. http://dx.doi.org/10.1016/j.asr.2013.01.009

[22] Staiger, C.J. (2000) Signaling to the Actin Cytoskeleton in Plants. Annual Review of Plant Physiology and Plant Molecular Biology, 51, 257-288. http://dx.doi.org/10.1146/annurev.arplant.51.1.257

[23] Wang, L., Ma, C.H. and Zhao, J.X. (2003) The Effects of HMC-Toxin on the Protoplasts and Their Actin Filaments Distribution in Detached Root Cap Cells of Charrua Cytoplasmic Male Sterility Maize. Acta Phytopathologica Sinica, 33, 225-228. (In Chinese)

[24] Lei, Y.H., Ma, C.H. and Wei, J.K. (2004) Effect of Pyricularia Oryzae Toxins on Distribution of Microfilament in Rice 
Root Cap Cells. Journal of Biology, 21, 17-18. (In Chinese)

[25] Ren, H.Y., Huang, Z.L., Chen, Z.L., Yuan, M. and Lu, T. (2000) Effect of $N^{+}$Ions Implantation on Pollen Germination and Microfilaments. Chinese Science Bulletin, 45, 390-394. (In Chinese)

[26] Yang, L.Y., Han, R. and Sun, Y. (2012) Damage Repair Effect of He-Ne Laser on Wheat Exposed to Enhanced Ultraviolet-B Radiation. Plant Physiology and Biochemistry, 57, 218-221.

[27] Zhang, Q. and Han, R. (2006) The Damage Repair Effects of He-Ne Laser on Intact Chloroplasts (in Vitro) Exposed to Enhanced UV-B Radiation. Cell Research, 16, 11.

[28] Han, R., Wang, X.L., Yue, M. and Qi, Z. (2002) Effects of the Enhanced UV-B Radiation on the Body Cell Mitosis of the Wheat. Acta Genetica Sinica, 29, 537-541. (In Chinese)

[29] Wyatt, S.E. and Carpita, N.C. (1993) The Plant Cytoskeleton-Cell-Wall Continuum. Trends in Cell Biology, 3, $413-417$. http://dx.doi.org/10.1016/0962-8924(93)90022-S 
Scientific Research Publishing (SCIRP) is one of the largest Open Access journal publishers. It is currently publishing more than 200 open access, online, peer-reviewed journals covering a wide range of academic disciplines. SCIRP serves the worldwide academic communities and contributes to the progress and application of science with its publication.

Other selected journals from SCIRP are listed as below. Submit your manuscript to us via either submit@scirp.org or Online Submission Portal.
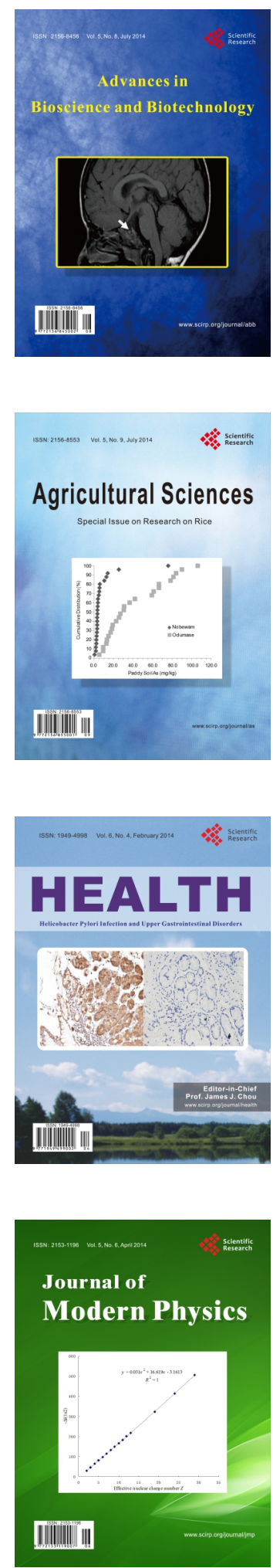
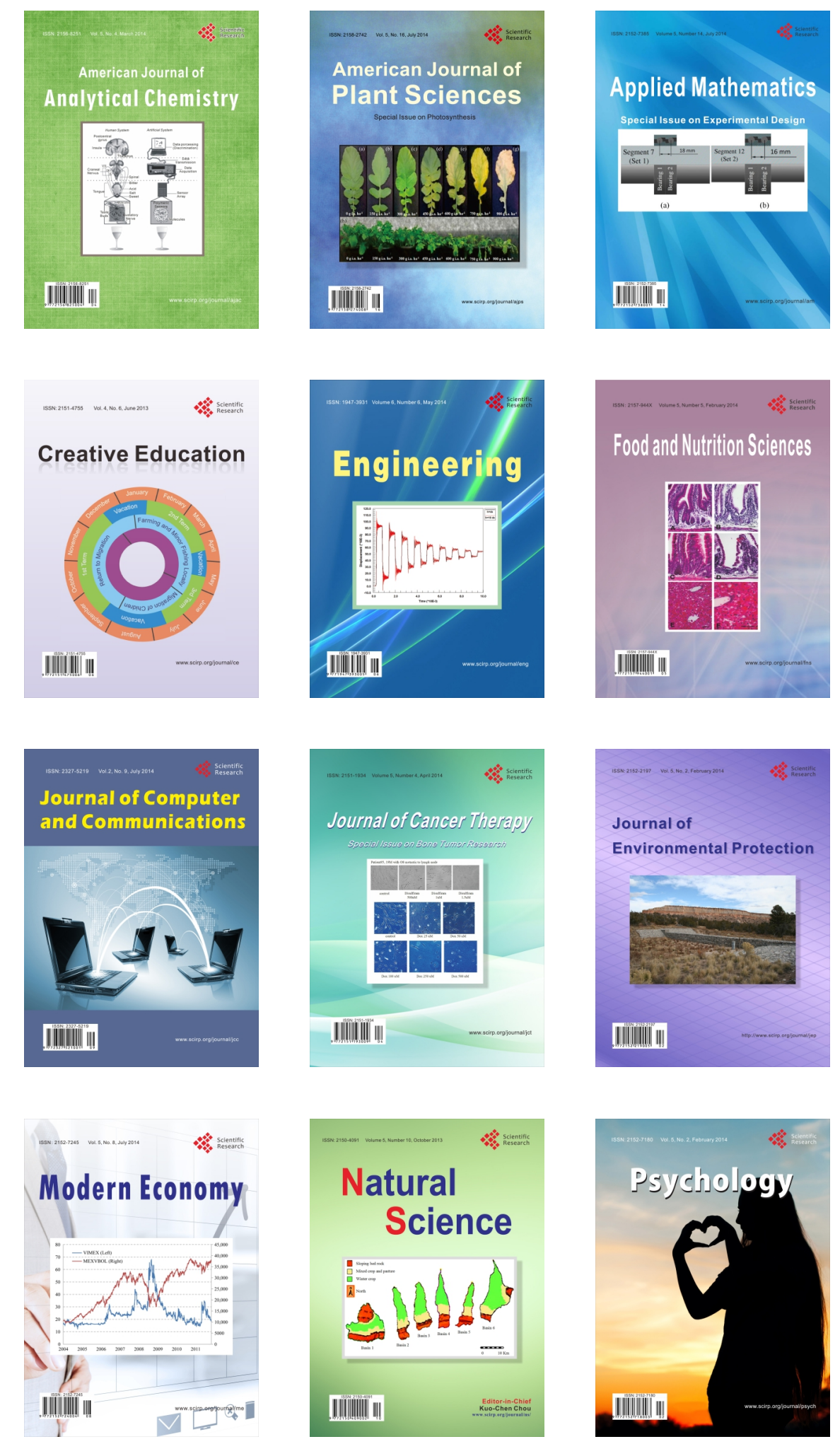